\title{
Geophysical Evaluation of Effectiveness of Blasting for Roof Caving During Longwall Mining of Coal Seam
}

\author{
Łukasz Wojtecki, ${ }^{1}$ Petr Konicek, ${ }^{2}$ Maciej J. Mendecki, ${ }^{3}$ (D) Iwona Gołda, ${ }^{4}$ and Wacław M. Zuberek ${ }^{3}$
}

\begin{abstract}
Deep longwall mining of coal seams is made in the Upper Silesian Coal Basin (USCB) under complicated and mostly unfavourable geological and mining conditions. Usually, it is correlated with rockburst hazard mostly at a high level. One of the geological factors affecting the state of rockburst hazard is the presence of competent rocks in the roof of extracted coal seams, so rock falling behind the longwall face does not occur, and hangingup of roof rocks remains. The long-lasting absence of caving may lead to an occurrence of high-energy tremor in the vicinity of the longwall face. Roof caving behind the longwall face may be forced by blasting. The column of explosives is then located in blastholes drilled in layers of roof rocks, e.g. sandstones behind the longwall face. In this article, a characterization of tremors initiated by blasts for roof caving during underground extraction of coal seam no. 507 in one of the collieries in the USCB has been made using three independent methods. By the basic seismic effect method, the effectiveness of blasting is evaluated according to the seismic energy of incited tremors and mass of explosives used. According to this method, selected blasts gave extremely good or excellent effect. An inversion of the seismic moment tensor enables determining the processes happening in the source of tremors. In the foci of provoked tremors the slip mechanism dominated or was clearly distinguished. The expected explosion had lesser significance or was not present. By the seismic source parameters analysis, among other things, an estimation of the stress drop in the focus or its size may be determined. The stress drop in the foci of provoked tremors was in the order of $10^{5} \mathrm{~Pa}$ and the source radius, according to the Brune's model, varied from 44.3 to $64.5 \mathrm{~m}$. The results of the three mentioned methods were compared with each other and observations in situ. In all cases the roof falling was forced.
\end{abstract}

Key words: Blasting for roof caving, SMT inversion, seismic source parameters, seismic effect method, longwall mining with caving.

1 Central Mining Institute, Gwarków Square 1, 40-166 Katowice, Poland.

2 Department of Geomechanics and Mining Research, The Czech Academy of Sciences, Institute of Geonics, Studentska 1768, 70800 Ostrava-Poruba, Czech Republic.

3 Faculty of Earth Sciences, University of Silesia, Katowice, Bedzińska 60, 41-200 Sosnowiec, Poland. E-mail: maciej.mendecki@us.edu.pl

4 Faculty of Mining and Geology, Silesian University of Technology, Akademicka 2, 44-100 Gliwice, Poland.

\section{Introduction}

The extraction of coal seams in the USCB is performed under complicated mining and geological conditions. The factors responsible for most occurrences of rockburst hazard are a large depth of exploitation, affecting a high-stress level in the rock mass; competent rocks in the roof of extracted coal seams; and faults, edges and remnants of surrounding coal seams, created during earlier and unclean exploitation. A rockburst is a dynamic, catastrophic phenomenon, causing the destruction of mine openings and supports. Because of that, underground excavations often lose their functionality. This phenomenon is very often associated with the destruction of machines and other underground infrastructure objects, and it is dangerous for the crew working in underground excavations. To prevent the rockburst phenomenon in the USCB, many countermeasures had been worked out, but the most important is blasting. There are two main types of blasting in hard coal mines which are a part of rockburst prevention: concussion blasting in the coal seam and long-hole destress blasting in the roof or floor rocks of the coal seam.

However, if there are competent rocks in the roof of the extracted coal seam, caving may not be present. This situation is disadvantageous from the rockburst hazard point of view. Hanging-up of roof rocks behind the longwall face with subsequent sudden roof caving may be a reason for high-energy tremor occurrence. The dynamic impact on the coal seam in the vicinity of the longwall face may be so high that it may lead to a coal bump. In such situation, a roof caving may be forced by blasting. 
Systematic blasts for roof caving enable regular and safe longwall face advance.

The effect of blasting for roof caving is clearly seen. It can be immediately found if caving was forced or not. Moreover, if the blasting is effective and roof caving really occurs, then it is accompanied by a tremor of energy higher than what would be expected from the mass of explosives used. The presence of additional geomechanical processes in the rock mass is reflected in registered tremor and its energy. The same assumption concerns the effect of concussion blasting in coal seams or long-hole destress blasting in surrounding rocks, used as a form of rockburst prevention, but their effect cannot be directly seen. Some methods to estimate the effectiveness of blasting have been worked out in the past, e.g. calculation of the radius of crack zone out of blasthole, numerical simulations using the pressure generated by the chemical energy in an explosive etc. They concern the blasting effect due to detonation of explosives itself. Proposed methods inform about provoking of geomechanical processes in rock mass due to blasting, mechanism of these processes and their scale.

In the presented article, we wanted to compare the real observations from the underground excavation with the calculated geophysical parameters of tremors provoked during longwall mining of coal seam no. 507 in one of the mines in the USCB. Because of hanging-up of roof rocks behind the longwall face, the necessity of blasting for roof caving occurred (Fig. 1). The results could be transferred for destress blasting, which effects cannot be directly seen.

According to the seismic effect method, where the energy of provoked tremors and the mass of used explosives are compared, the effectiveness of each blasting has been estimated. This method was developed in the Czech Republic (Konicek et al. 2013). It was then implemented in assigned Polish hard coal mine (Wojtecki and Konicek 2016). The seismic effect method was basically created for longhole destress blasting. If the energy of a provoked tremor was higher than what would be expected from the mass of explosives used, it testifies that other additional geomechanical processes were triggered in surrounding rock masses. Blasting can be classified as effective if additional processes in the rock mass lead

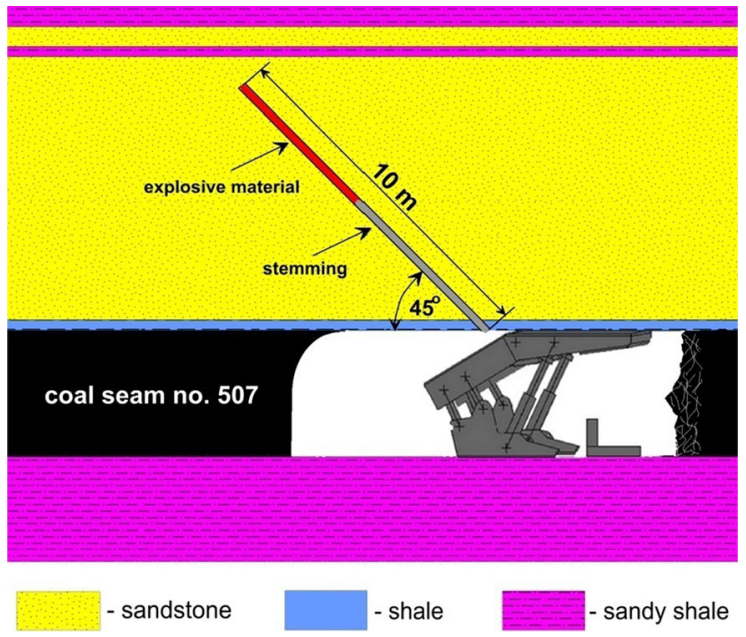

Figure 1

One of the blastholes behind the longwall face to induce roof caving

to an energy release and a transition of the rock mass to a new stable equilibrium state occurs. In the selected longwall, every blasting for roof caving gave a positive effect.

The focal mechanism and seismic source parameters of each provoked tremor have been calculated too. If there are no other processes, only an explosion due to the detonation of explosives should be present in the foci. However, an occurrence of another process, provoked by blasting, should be reflected in the wave pattern and thus in the solution of the seismic moment tensor (SMT) and seismic source parameters.

The effects of blasting for roof caving with the presented parameters and under specific geological and mining conditions have been analysed for the first time by three different methods and compared with the observations in situ. The occurrence of geomechanical processes had their reflection in the calculated parameters. The explosion did not dominate in the foci of tremors, initiated by blasting.

\section{Conditions of Mining}

The selected longwall in one of the Polish deep hard coal mines in the USCB had been designed in coal seam numbered 507. This coal seam was mined in a longwall system with caving. Coal seam no. 507 
was deposited there at a depth of between $814 \mathrm{~m}$ below surface (564 $\mathrm{m}$ b.s.l.) and $884 \mathrm{~m}$ below surface (634 m b.s.1.). Its thickness varies from 3 to $4.1 \mathrm{~m}$, and inclination is, generally, in the direction WNWESE-from $2^{\circ}$ to $16^{\circ}$. The uniaxial compressive strength of this coal seam is above $16 \mathrm{MPa}$, what testifies about its ability to accumulate energy and burst. According to experiences and investigation in USCB, if uniaxial compressive strength is lower than $16 \mathrm{MPa}$ the coal seam does not have the tendency to burst.

In the immediate roof, layers of shale and locally sandy shale are present. A few-metre layer of sandstone is present above. These roof rocks are mostly competent. Their uniaxial compressive strength reaches maximally about $70 \mathrm{MPa}$. About $30 \mathrm{~m}$ above the extracted coal seam no. 507, a series of thick layers of sandstones occurs, with interbedding mostly of sandy shales. The uniaxial compressive strength of these sandstones equals about $80 \mathrm{MPa}$. Generally, rocks laying in the immediate roof of extracted coal seam no. 507 had a tendency to hang-up behind the longwall face, creating a danger of strain energy accumulation.

The floor of the extracted coal seam no. 507 is composed of shale and sandy shale. A thick coal seam, numbered 510, is deposited below. The thickness of this coal seam reaches $8.5 \mathrm{~m}$. The distance between coal seams no. 507 and no. 510 varies in this region from $2.1 \mathrm{~m}$ to $8.6 \mathrm{~m}$ only.

Three coal seams numbered nos. 502, 504, and 506, deposited, respectively, at about $124 \mathrm{~m}$, 61-70 m, and $27 \mathrm{~m}$ above coal seam no. 507, have been extracted earlier. These coal seams were extracted, respectively, at about 12-22, 10-13, and 36-37 years before the exploitation in coal seam no. 507 with the selected longwall. Coal seam no. 502 was extracted in total, while the extraction of coal seams nos. 504 and 506 created edges above the field of the selected longwall (Fig. 2). These edges are boundaries of exploitation, potentially increasing the stress level in the rock mass. Coal seam no. 504 was mined by two different longwalls. The range of coal seam no. 504 exploitation, determined by the past mining situation, was responsible for the edge orientation. The extraction of coal seam no. 506 was not continued to the south, because of low thickness.
Initially, the longwall face was hidden under the goaf created by an earlier extraction of all mentioned coal seams. But, it was partly under the theoretical influence of the edge of the coal seam no. 506 (Fig. 2). However, the extraction of the coal seam no. 506 was so long ago that it theoretically influenced the stress level in a lesser degree.

The length of the selected longwall was about $198 \mathrm{~m}$, and its maximum height equalled $3.8 \mathrm{~m}$. The extraction began from the longwall cross-cut on the north-west, and then the longwall face moved to the south-east. In the original plan, the longwall cross-cut was designed to the south-east from abandoned goaf in the upper stage and separated from it by a rib of coal, about 5 metres wide (Fig. 2). Spontaneous combustion in that goaf was a reason for redesigning the longwall cross-cut location. It was drilled once more, at a distance of about $30 \mathrm{~m}$ to the south-east. The advantageous solution against spontaneous fire hazard was not so good from the rockburst hazard point of view. A remnant created in coal seam no. 507 precluded a roof caving behind the face of the selected longwall. Moreover, an increased stress level might be present within the remnant in the coal seam.

\section{Blasting for Roof Caving}

The presented geological and mining conditions, i.e. competent rocks in the roof of coal seam no. 507 with a tendency to hang-up, ability of coal seam no. 507 to burst, remnant between old goaf and second location of longwall cross-cut, influenced the absence of regular roof caving behind the longwall face. It necessitated the application of blasting for roof caving. In total, 6 blasts were performed for roof caving, but 5 of them were taken into consideration (Fig. 2). One blasting for roof caving (4 blastholes, $96 \mathrm{~kg}$ of explosives) was executed together with the destress blasting from the tail gate. Because the distance between blastholes exceeded $100 \mathrm{~m}$, the common result of these two blasts has been ignored.

The blastholes were drilled perpendicularly from the longwall face, in the direction of the remnant left in coal mine no. 507. The number of blastholes was variable, from 1 to 5 . The blastholes were about $10 \mathrm{~m}$ long with inclination about $45^{\circ}$. The diameter of 


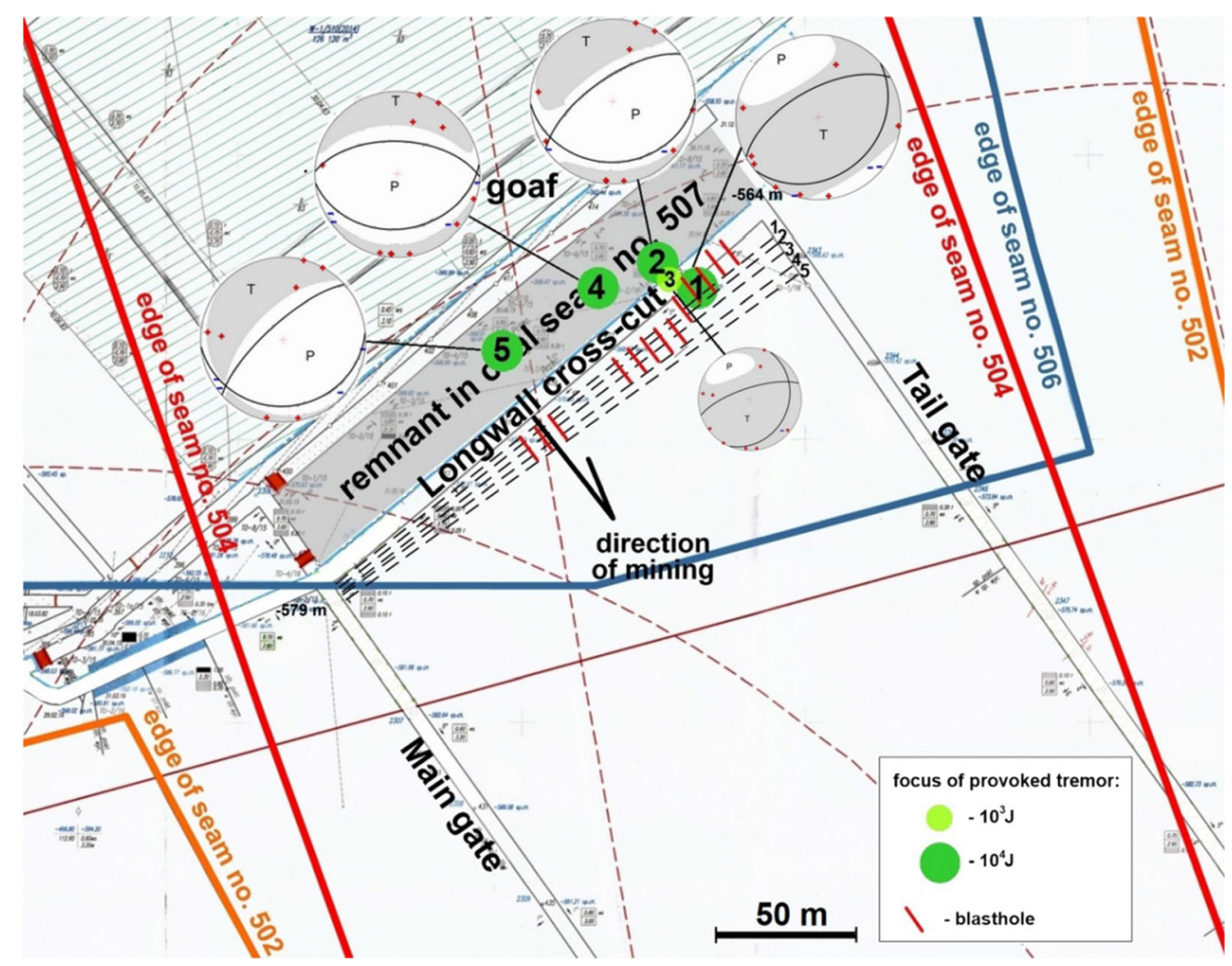

Figure 2

Map of coal seam no. 507 with the location of blastholes for roof caving, foci of provoked tremors, and beachballs, representing projection of nodal planes for the full SMT solution

blastholes equalled $76 \mathrm{~mm}$. The explosives were always loaded pneumatically in blastholes. A single blasthole was charged with $24 \mathrm{~kg}$ of explosives, i.e. Emulinit PM and stemming. The cartridge containing Emulinit PM has minimum diameter $32 \mathrm{~mm}$ and it weighs $300 \mathrm{~g}$ (Nitroerg 2019). The density of this explosive material equals $1.15-1.3 \mathrm{~g} \mathrm{~cm}^{-3}$. To the other parameters we can include e.g. the average detonation velocity $\left(4500 \mathrm{~ms}^{-1}\right)$, the specific energy $\left(522 \mathrm{~kJ} \mathrm{~kg}^{-1}\right)$, heat energy $\left(2278 \mathrm{~kJ} \mathrm{~kg}^{-1}\right.$ ) (Nitroerg 2019). The column of explosives in a single blasthole was approximately $5 \mathrm{~m}$ long and was located in total in the layer of sandstone (Fig. 1). To stem the blastholes, cylinder-shaped paper bags containing clay and sand were used.

The self-executed blasts for roof caving directly provoked tremors which had seismic energy $E$ from $7 \times 10^{3} \mathrm{~J}$ to $5 \times 10^{4} \mathrm{~J}$, which corresponds with the local magnitude $M_{L}$ from 1.08 to 1.53 . The values of the local magnitude $M_{L}$ were calculated according to the given formula $\log E=1.8+1.9 M_{L}$ (Dubiński and Wierzchowska 1973). After each of the mentioned blasts, a roof caving occurred. From this point of view, all of the described blasts can be acknowledged as effective. The parameters of the provoked tremors have been determined.

\section{Methods}

\subsection{Seismic Effect Method}

The seismic effect method has been basically designed for destress blasting (Knotek et al. 1985; Konicek et al. 2013, Wojtecki and Konicek 2016). This blasting is found as effective if the stress release in the rock mass took place. It has a reflection on the seismic effect (SE) value (Knotek et al. 1985; 
Konicek et al. 2013). SE can be calculated via dividing the seismic energy, which is released in the rock mass due to blasting, by the energy of detonation of the used mass of explosives from all the blastholes, thus SE considers natural and mining conditions of the colliery (Konicek et al. 2013). The seismic effect method could be used for other types of blasting which provoke some geomechanical processes and release energy from it, e.g. blasting for caving. Generally, the seismic effect can be calculated as a ratio of seismic energy $E_{I C M}$, measured by the mining seismic network and mass of the explosive charge $Q$ multiplied by a coefficient $K_{I C M}$, characterizing the conditions in the assigned mine (Wojtecki and Konicek 2016).

The seismic energy of tremors in the selected hard coal mine is calculated commonly using the numerical integration method. The square of the velocity amplitude in the following samples, sampling rate, distance between focus and seismic station, density and attenuation coefficient of rock mass, seismic wave velocity, and the calibration factor are the parameters for energy calculation on each seismic station. The energies of all seismic stations are averaged, which gives the final seismic energy $E_{I C M}$ of each tremor. The energy of a tremor being higher than what would be expected from the mass of explosives used testifies about some other processes occurrence. These processes lead it to a new equilibrium state in the rock mass.

The coefficient $K_{I C M}$ has to be determined, concerning conditions under which the seismic monitoring is performed. The seismic energy of tremors has to be calculated in an identical way (Konicek et al. 2013). Generally, this method uses statistical analysis of following data: the seismic energies from in situ monitoring and the mass of the explosive charges. This coefficient was calculated for the selected colliery and equals $K_{I C M}=59.23 \mathrm{~J} / \mathrm{kg}$ (Wojtecki and Konicek 2016), and it was used to create the classification system to evaluate the seismic effect (SE). The criteria were established using the data probability from the calculated seismic effects. From the whole dataset of SE, the statistical values were taken: first quantile (1.4), median (2.3), third quantile (3.5), maximum (5.9), and so the outliers. The stress release degrees were determined.
If SE was lower than the first quantile, it means that the seismic energy of provoked tremor was less than 1.4. times the energy expected from the used mass of explosives, and so the effect was insignificant. An SE higher than the maximum (outliers) was excellent, i.e. energy released from rock mass was higher than 5.9 times the energy coming from the detonation of explosives. The classification system developed to evaluate the seismic effect is shown in Table 1.

\subsection{Seismic Moment Tensor Inversion Method}

The seismic moment tensor (SMT) inversion method is used for the calculation of focal mechanisms. This method, originally applied for natural seismic events-earthquakes (e.g. Sykes 1967; Backus and Mulcahy 1976), was next transferred to calculate focal mechanisms of mine tremors (e.g. Gibowicz et al. 1977; Hasegawa et al. 1989; Gibowicz 1989; Dubiński et al. 1996; Stec 2007; Gibowicz 2009; Lizurek and Wiejacz 2011). The basic assumption of this method is that the displacements at the far-field are a sum of displacements due to each of the force couples (Aki and Richards 1980) acting in the source, thus the seismic moment tensor defines the force system occurring in seismic point source. It is considered as a linear combination of force couples, and it describes entirely and completely the seismic source in the focus (Backus and Mulcahy 1976). The SMT can be decomposed into an isotropic part I, describing the volumetric changes ("+"-explosion and "-"-implosion) and a deviatoric part, which can be further decomposed into a compensated linear vector dipole (CLVD), describing a mechanism

Table 1

Classification system for the evaluation of SE in the assigned hard coal mine (Wojtecki and Konicek 2016)

\begin{tabular}{lll}
\hline $\begin{array}{l}\text { Seismic effect } \\
(\mathrm{SE})\end{array}$ & $\begin{array}{l}\text { Evaluation of seismic } \\
\text { effect }\end{array}$ & $\begin{array}{l}\text { Percentage of } \\
\text { dataset }\end{array}$ \\
\hline$S E<1.4$ & Insignificant & 20.7 \\
$1.4 \leq S E<2.3$ & Good & 29.1 \\
$2.3 \leq S E<3.5$ & Very good & 25.1 \\
$3.5 \leq S E<5.9$ & Extremely good & 19.5 \\
$S E \geq 5.9$ & Excellent & 5.6 \\
\hline
\end{tabular}


similar to the uniaxial compression ("-") or tension ("+”) and a double couple of forces (DC), describing a pure shear mechanism. Domination of the double couple mechanism of forces (DC) indicates the sliding along the failure plane. It is the most used description of the mechanism of mine tremors (Gibowicz et al. 1977; Gibowicz 1989; Stec 2007; Lizurek and Wiejacz 2011; Wojtecki et al. 2016a).

Some attempts were made applying the SMT inversion method for the tremors provoked by blasting in mines, which were published in a $\mathrm{PhD}$ dissertation (Król 1998) and after in works by Wojtecki et al. (2013), Caputa et al. (2015), and Wojtecki et al. (2016a). It can be determined if the only explosion because of the detonation of explosive material took place or other processes, e.g. sliding of the rock blocks or implosion, took place in the focus of the provoked tremor. Focal mechanisms have been calculated by the SMT inversion using the seismic waves generated in the foci of provoked tremors and registered by the mine seismic network, consisting of 15 underground seismic stations. These seismic stations were located at a depth from $160 \mathrm{~m}$ to $1000 \mathrm{~m}$ below sea level $(410 \mathrm{~m}$ to $1250 \mathrm{~m}$ below surface) and in different layers of rock mass. There are short-period SPI-70 seismometers and low-frequency DLM-2001 geophones, measuring the vertical velocity of ground motion. The epicentre of tremors was localized, with the error between 25 and $38 \mathrm{~m}$. The error of the vertical coordinate $\mathrm{Z}$ was between about $47 \mathrm{~m}$ and about $59 \mathrm{~m}$, assuming seismic wave first arrival time error of $10 \mathrm{~ms}$ and velocity model error of $20 \mathrm{~m} / \mathrm{s}$. To calculate the seismic moment tensor of provoked tremors the FOCI software was applied (Kwiatek et al. 2016). These calculations were made by the inversion of P-wave amplitude, taking into consideration the directions of the first arrivals in the time domain, and with the use of norms L1 and L2. In both cases, the results were convergent. However, for better certainty, the results obtained using norm L1 have been accepted as final. This is because of its lower dependence on possible large errors, caused, e.g. by random noise produced by mining operation or transport machines. The depth of each focus was calculated once more by the FOCI software (Kwiatek et al. 2016). The vertical coordinate $\mathrm{Z}$ was improved, testing the SMT solution and assuming the result corresponding to the lowest value of estimation error and the highest value of quality coefficient, taking into consideration the seismic stations configuration. The full SMT decomposition of provoked tremors was done. The percentage share of the I, CLVD and DC was calculated. If the DC component equals $50 \%$ or more, the solution is classified by the authors as a normal (NO) or eventually as a reverse (RE) slip mechanism (according to the direction of sliding movement). If the I component dominates the solution, it is classified as an explosion (EXPL) or implosion (IMPL) mechanism. In some cases, a mixed mechanism in the focus of the provoked tremor could be present, e.g. NO/ IMPL or RE/EXPL. When the DC component dominates or is clearly distinguished, it is wellfounded to determine the two perpendicular nodal planes (A and B) parameters (e.g. $\Phi$ - strike angle, $\delta$-dip angle, $\lambda$-rake angle). It is assumed that one of the nodal planes represents the real fault plane, and the second one is an auxiliary plane.

\subsection{Seismic Source Parameters}

They were first calculated for earthquakes and then for seismic events induced in rock mass by mining, e.g., in deep gold mines (McGarr et al. 1989), in copper mines (Trifu et al. 1995; Orlecka-Sikora et al. 2012; Lizurek and Wiejacz 2011; Lizurek et al. 2015; Rudziński et al. 2016) and in hard coal mines (Gibowicz and Kijko 1994; Dubiński et al. 1996). They were not often calculated for seismic events being a result of blasting (e.g., Srinivasan et al. 2005; Wojtecki et al. 2017a, b). These parameters describe the focus of the tremor and to a certain degree inform about processes and their scale occurring there. These parameters are calculated on the basis of seismic station records. By integrating the velocity $V(f)$ and displacement $D(f)$ amplitude spectra in the frequency domain, two parameters $J$ and $K$ are calculated (Andrews 1986; Snoke 1987; Mendecki 1997; Kwiatek et al. 2016). By definition, the integrals impose constraints at positive and negative infinity, but practically both of them are calculated for finite frequency limits, lower $f_{1}$ and upper $f_{2}$. It underestimates the $J$ and $K$ power spectra, and according to Mendecki 1997 must be corrected. The integrals 
$J$ and $K$ enable the calculation of the two basic and independent seismic source parameters, i.e. lowfrequency spectral level $\Omega_{o}$ and corner frequency $f_{o}$. These two parameters enable to obtain other seismic source parameters, e.g. scalar seismic moment $M_{o}$, moment magnitude $M_{w}$, seismic energy $E_{c}$, source radius $r$, stress drop $\Delta \sigma$, and apparent stress $\sigma_{a}$. The first of them estimates the overall size of the seismic source and is also a measure of energy of the tremor, and depends on the low-frequency spectral level. The scalar seismic moment $M_{o}$ is a static parameter and is proportional to terminal average displacement on a fault (Aki and Richards 1980; McGarr et al. 1989; Gibowicz and Kijko 1994; Trifu et al. 1995), and it is applied for the moment magnitude $M_{w}$ calculation (Hanks and Kanamori 1979). It represents the magnitude of seismic event, in terms of how much energy was released. Another parameter that is evaluated from signal spectra is the seismic energy $E_{c}$, and it reflects shock dynamics, as opposed to scalar seismic moment which is static (Gibowicz and Kijko 1994). If the rupture velocity is slower, the less energy is radiated (Mendecki 1997). The seismic energy $E_{c}$ is calculated in a different way, as compared with the $E_{I C M}$. The seismic energy $E_{c}$ can be calculated independently for P-wave $\left(E_{p}\right)$ and S-wave $\left(E_{s}\right)$, and the ratio $E_{s}$-to- $E_{p}$ indicates the mechanism of the dynamic processes. According to this ratio, the presence of shear or non-shear mechanism can be estimated. The ratio $E_{s}$-to- $E_{p}$ higher than 20 suggests, in case of copper mines, that the DC component dominates in the focal mechanism described by SMT (Król 1998; Lizurek and Wiejacz 2011), and below it the other non-shear components are also present (Lizurek and Wiejacz 2011). Trifu et al. (1995) demonstrated that in case of the lower limit 10, analogous situation can take place. The next source parameter is the source radius $r$, and it is calculated on the basis of the S-wave velocity $V_{s}$ and the corner frequency $f_{o}$. The value of the source radius $r$ depends on the assumed source model. Two of them are commonly used, made by Brune (1970) and Madariaga (1976). In both of them the source has a circular shape. According to Trifu et al. (1995) the source radius calculated assuming the Madariaga's source model is usually two times smaller than in case of Brune's source model. It differs for copper, gold or coal mines and varies from several to hundreds of metres. Smaller values were observed in hard coal mines (Dubinski et al. 1996). Calculations for tremors provoked by blasting in hard coal mines (Wojtecki et al. 2016b, 2017a, b) gave the source radius from about $20 \mathrm{~m}$ to about $150 \mathrm{~m}$, depending on the blasting parameters, geological and mining conditions, and assumed source model. On the basis of source radius, the static stress drop $\Delta \sigma$ can be calculated (Aki and Richards 1980; McGarr et al. 1989; Trifu et al. 1995). This parameter informs about the difference in stress levels before and after the tremor occurrence. The static stress drop $\Delta \sigma$ depends strongly on the assumed source model. In case of tremors after blasting in a hard coal mine, the stress drop $\Delta \sigma$ equalled from about $2.5 \times 10^{5} \mathrm{MPa}$ to about $3.05 \times 10^{6} \mathrm{MPa}$ (Wojtecki et al. 2016b, 2017a, b). The last seismic source parameter is the apparent stress $\sigma_{a}$ that is defined as radiated energy per unit area per unit slip. Practically, it does not depend on the assumed source model and does not inform about the real stress drop (Aki and Richards 1980; McGarr et al. 1989; Trifu et al. 1995). It can be treated as hazard factor. High values represent failure in non-fractured rock mass, which is example of high seismic hazard. Low values are associated with failure on the present fault, fractured zones and other weakened zones (Gibowicz and Kijko 1994).

\section{Results}

Seismic waves generated in the foci of tremors, provoked by blasting for roof caving, and then registered by the seismological network, were used to determine the seismic effect, the SMT and the seismic source parameters. After every blast, a roof caving behind the longwall face occurred. Additional processes leading the rock mass to a new advantageous equilibrium state affected the energy of provoked tremors and other parameters.

The seismic effect method classified the considered results of blasts as extremely good or excellent (Table 2). Every time, the energy of provoked tremors was higher than what would be expected from the mass of explosives used-from 3.5 to 7 times. 
Table 2

Seismic effect of blasting for roof caving

\begin{tabular}{lllllll} 
No. $Q(\mathrm{~kg})$ & $\begin{array}{l}\text { No. of } \\
\text { blastholes }\end{array}$ & $E_{I C M} \times 10^{4}(\mathrm{~J})$ & $M_{L}$ & $S E$ & $\begin{array}{l}\text { Evaluation } \\
\text { of } S E\end{array}$ \\
\hline 1. & 48 & 2 & 1 & 1.16 & 3.5 & $\begin{array}{c}\text { Extremely } \\
\text { good }\end{array}$ \\
2. & 48 & 2 & 1 & 1.16 & 3.5 & $\begin{array}{c}\text { Extremely } \\
\text { good }\end{array}$ \\
3. & 24 & 1 & 0.7 & 1.08 & 4.9 & $\begin{array}{c}\text { Extremely } \\
\text { good }\end{array}$ \\
4. & 120 & 5 & 5 & 1.53 & 7 & $\begin{array}{c}\text { Excellent } \\
\text { Excellent }\end{array}$ \\
5. & 72 & 3 & 3 & 1.41 & 7 & \\
\hline
\end{tabular}

According to the seismic effect method, in the foci of provoked tremors, some other processes occurred, and not only explosion due to detonation of explosives was present.

The most probable focal mechanisms of tremors provoked by blasting for roof caving have been determined via the SMT inversion (Table 3). The foci depth calculated from the best-fitting solution by the FOCI software ranges from -579 to $-600 \mathrm{~m}$ below sea level, which corresponds precisely with the depth of the roof rocks of coal seam no. 507, where the column of explosive material was loaded. In all cases, a shear mechanism dominated. The share of the DC component for these tremors varies from 38.8 to
$60.8 \%$ (average 49.1\%), as shown in Table 3. The share of the absolute value of I component for these tremors ranges from 24 to $40.5 \%$ (average $31.6 \%$ ). The CLVD component has the lowest share in the full solution of the seismic moment tensor-absolute value between 5.9 and $29.1 \%$ (average 19.3\%).

In the focus of the tremor after blast no. 2, a normal slip mechanism (NO) clearly dominated (60.8\%), but an implosion and uniaxial compression were also present (respectively, $-24 \%$ and $-15.3 \%$ ), as shown in Table 3. In the foci of tremors after blasts nos. 4 and 5, a mixed mechanism occurred, composed mostly of normal slip mechanism and implosion (NO/IMPL). The DC component dominated (respectively, 38.8 and $42.4 \%$ ), but it was not so clear in comparison with the other focal mechanisms. The shares of other components were also significant-implosion, respectively $-32.1 \%$ and $-29 \%$; and uniaxial compression, respectively, $-29.1 \%$ and $-28.7 \%$ (Table 3). In the foci of tremors after blasts nos. 1 and 3, a reverse slip mechanism (RE) dominated (respectively, 50\% and $53.7 \%$ ), however a share of the explosion was also high (respectively, 32.5\% and 40.5\%), as shown in Table 3. In the focus of the tremor after blast no. 1, a uniaxial compression occurred $(-17.4 \%)$, but in the focus of the tremor after blast no. 3 a small share of uniaxial tension $(5.9 \%)$ was present.

Table 3

Focal mechanism parameters of tremors provoked by blasting for roof caving

\begin{tabular}{|c|c|c|c|c|c|c|c|c|c|c|}
\hline \multirow[t]{2}{*}{ No. } & \multirow[t]{2}{*}{$Q(\mathrm{~kg})$} & \multirow{2}{*}{$\begin{array}{l}\text { No. of } \\
\text { blastholes }\end{array}$} & \multirow{2}{*}{$\begin{array}{l}E_{I C M} \times 10^{4} \\
(\mathrm{~J})\end{array}$} & \multirow{2}{*}{$\mathrm{Z}^{1}(\mathrm{~m})$} & \multicolumn{3}{|c|}{ Components of full seismic moment tensor (\%) } & \multirow[t]{2}{*}{ Type mechanism } & \multicolumn{2}{|c|}{ Nodal plane parameters ${ }^{2}$} \\
\hline & & & & & I & CLVD & DC & & $\begin{array}{l}\Phi \mathrm{A} / \delta \mathrm{A} \\
\lambda \mathrm{A}\end{array}$ & $\begin{array}{l}\Phi \mathrm{B} / \delta \mathrm{B} \\
\lambda \mathrm{B}\end{array}$ \\
\hline 1. & 48 & 2 & 1 & -579 & 32.5 & -17.4 & 50 & $\mathrm{RE}$ & $\begin{array}{l}241.1^{\circ} / 62.2^{\circ} \\
95.6^{\circ}\end{array}$ & $\begin{array}{l}49.2^{\circ} / 28.3^{\circ} \\
79.5^{\circ}\end{array}$ \\
\hline 2. & 48 & 2 & 1 & -600 & -24 & -15.3 & 60.8 & NO & $\begin{array}{l}234.8^{\circ} / 67^{\circ} \\
-104.4^{\circ}\end{array}$ & $\begin{array}{l}88.1^{\circ} / 27^{\circ} \\
-59.6^{\circ}\end{array}$ \\
\hline 3. & 24 & 1 & 0.7 & -585 & 40.5 & 5.9 & 53.7 & RE & $\begin{array}{l}251.9^{\circ} / 72.4^{\circ} \\
108.9^{\circ}\end{array}$ & $\begin{array}{l}23.4^{\circ} / 25.6^{\circ} \\
44.5^{\circ}\end{array}$ \\
\hline 4. & 120 & 5 & 5 & -593 & -32.1 & -29.1 & 38.8 & NO/IMPL & $\begin{array}{l}271.8^{\circ} / 57.2^{\circ} \\
-85.4^{\circ}\end{array}$ & $\begin{array}{l}83.4^{\circ} / 33.1^{\circ} \\
-97.1^{\circ}\end{array}$ \\
\hline 5. & 72 & 3 & 3 & -591 & -29 & -28.7 & 42.4 & NO/IMPL & $\begin{array}{l}227.9^{\circ} / 73.9^{\circ} \\
-101.9^{\circ}\end{array}$ & $\begin{array}{l}85.1^{\circ} / 20^{\circ} \\
-54.5^{\circ}\end{array}$ \\
\hline
\end{tabular}

${ }^{1}$ Focus depth improved by the FOCI software (solution characterized by the lowest error value and the highest quality coefficient value)

${ }^{2}$ Parameters of nodal planes: $\Phi A, \Phi B$ azimuth of nodal plane A, B, $\delta A, \delta B$ dip of nodal plane A, B, $\lambda A, \lambda B$ rake angle connected with nodal plane A, B 
For all provoked tremors, the nodal plane parameters for the DC component have been determined (Table 3). The strike angle of the nodal plane A clearly corresponds to the longwall face orientation (from $234.8^{\circ}$ to $271.8^{\circ}$ ). The other parameters of the nodal plane A-dip and rake angles-are comparable. The dip angle of the nodal plane A ranges between $57.2^{\circ}$ and $73.9^{\circ}$ (average $66.5^{\circ}$ ). In the foci of tremors after blasts nos. 2, 4 and 5, the rock blocks moved directly to the direction of the remnant in coal seam no. 507 (rake angle between $-85.4^{\circ}$ and $-104.4^{\circ}$, average $-97.2^{\circ}$ ). In the other two cases, where the reverse slip mechanism dominated, the parameters were comparable, but the movement was in the opposite direction.

A map of coal seam no. 507 with the location of blastholes, foci of provoked tremors (circles with the numbers of blasts) and beachballs (representing focal mechanisms) is shown in Fig. 2. In each beachball, the shaded area indicates tension, and continuous lines indicate projection of nodal planes on the lower hemisphere. The longwall face advances at the moments of blasts nos. 1-5 are represented in Fig. 2 by broken lines with appropriate number.

In Table 4, the seismic source parameters of tremors initiated by blasting for roof caving are collected. Blasts parameters were variable (e.g. a number of blastholes: 1-5, weight of explosives: 24-120 kg), so their effects already should be different from each other, however most of the seismic source parameters of provoked tremors are characterised by a low variability. The low-frequency spectral level $\Omega_{o}$ ranges from $1.12 \times 10^{-8}$ to $3.09 \times 10^{-8}$ (average $2.39 \times 10^{-8}$ ). The corner frequency $f_{o}$ varies from $12.27 \mathrm{~Hz}$ to $16.89 \mathrm{~Hz}$ (average $15.28 \mathrm{~Hz}$ ). The scalar seismic moment $M_{o}$ equals from $3.26 \times 10^{10} \mathrm{Nm}$ to $1.47 \times 10^{11} \mathrm{Nm}$ (average $8.58 \times 10^{10} \mathrm{Nm}$ ). The moment magnitude $M_{w}$ varies from 0.93 to 1.29 (average 1.16). The seismic energy $E_{c}$ calculated for $\mathrm{P}$-waves and $\mathrm{S}$-waves together ranges from $1.44 \times 10^{4} \mathrm{~J}$ to $6.96 \times 10^{4} \mathrm{~J}$ (average $3.67 \times 10^{4} \mathrm{~J}$ ). Values of the ratio $E_{s} / E_{p}$ range between 3.7 and 9.3 (average 5.6). The source radius $r$ (assuming Brune's source model) equals from 44.3 to $64.5 \mathrm{~m}$ (average $51.4 \mathrm{~m}$ ) and is higher in comparison with the arrangement of blastholes. The diameters calculated on the basis of obtained source radii are comparable with the halflength of the longwall face. These values are slightly overestimated, probably because of the accepted source model assumptions. The stress drop $\Delta \sigma$ varies from $3.37 \times 10^{5} \mathrm{~Pa}$ to $7.63 \times 10^{5} \mathrm{~Pa}$ (average $4.6 \times 10^{5} \mathrm{~Pa}$ ). The apparent stress $\sigma_{a}$ is between $6.1 \times 10^{3} \mathrm{~J} / \mathrm{m}^{3}$ and $1.29 \times 10^{4} \mathrm{~J} / \mathrm{m}^{3}$ (average $\left.9.5 \times 10^{3} \mathrm{~J} / \mathrm{m}^{3}\right)$.

\section{Discussion and Conclusion}

The occurrence of the hanging roof behind the longwall face influences on rockburst hazard. Such situation took place during extraction of coal seam no. 507 in selected hard coal mine in USCB. Deposition of competent rocks in the immediate roof and leaving the 30-m-wide remnant in this coal seam behind the longwall cross-cut was responsible for the lack of roof layer falling during longwall mining. The first roof caving was achieved only as a result of

Table 4

Parameters of seismic sources being an effect of blasting for roof caving

\begin{tabular}{|c|c|c|c|c|c|c|c|c|c|c|c|c|}
\hline \multirow[t]{2}{*}{ No. } & \multirow[t]{2}{*}{$Q(\mathrm{~kg})$} & \multirow{2}{*}{$\begin{array}{l}\text { No. of } \\
\text { blastholes }\end{array}$} & \multirow{2}{*}{$\begin{array}{l}E_{I C M} \times 10^{4} \\
{[\mathrm{~J}]}\end{array}$} & \multicolumn{9}{|c|}{ Seismic source parameters } \\
\hline & & & & $\Omega_{o} \times 10^{-8}$ & $\begin{array}{l}f_{o} \\
(\mathrm{~Hz})\end{array}$ & $\begin{array}{l}M_{o} \times 10^{10} \\
(\mathrm{Nm})\end{array}$ & $M_{w}$ & $\begin{array}{l}E_{c} \times 10^{4} \\
(\mathrm{~J})\end{array}$ & $r(\mathrm{~m})$ & $\begin{array}{l}\Delta \sigma \times 10^{5} \\
(\mathrm{~Pa})\end{array}$ & $\begin{array}{l}\sigma_{a} \times 10^{4} \\
\left(\mathrm{~J} / \mathrm{m}^{3}\right)\end{array}$ & \\
\hline 1. & 48 & 2 & 1 & 2.23 & 16.81 & 6.73 & 1.1 & 2.37 & 48 & 3.89 & 0.61 & 4.6 \\
\hline 2. & 48 & 2 & 1 & 2.48 & 15.15 & 7.8 & 1.18 & 3.27 & 50.5 & 4.12 & 0.87 & 6.5 \\
\hline 3. & 24 & 1 & 0.7 & 1.12 & 16.89 & 3.26 & 0.93 & 1.44 & 44.3 & 3.98 & 1.29 & 9.3 \\
\hline 4. & 120 & 5 & 5 & 3.03 & 15.3 & 10.4 & 1.29 & 6.96 & 49.7 & 7.63 & 1.29 & 3.9 \\
\hline 5. & 72 & 3 & 3 & 3.09 & 12.27 & 14.7 & 1.29 & 4.31 & 64.5 & 3.37 & 0.7 & 3.7 \\
\hline
\end{tabular}


blasting. The parameters of blasts, such as number of blastholes, their location and so the total mass of the explosives was variable and accommodated to geological conditions and technical opportunities. Only length, direction, and inclination to the horizon of blastholes were stable, so the column of the explosive material was located each time in the layer of sandstone, deposited in the immediate roof of coal seam no. 507, above the thin layer of shale or sandy shale. Each blast for roof caving was effective (Fig. 2), which also was confirmed in situ.

The provocation of additional processes behind the longwall face was reflected in the energy of the provoked tremors in comparison with that which would be expected from the mass of explosives used. The provocation of additional processes (e.g. roof rock failure, a slip of rock blocks) is connected with the rock mass reaching a new equilibrium state. The destress effectiveness of blasts for roof caving has been estimated with the commonly used seismic effect method, based on the energy of the registered tremor and the mass of explosives used. The seismic effect method indicates that each blast for roof caving initiated additional processes in rock mass, and strain energy was released. The energy of the provoked tremors was 3.5-7 times higher than that from the detonation of explosives.

After that, the focal mechanisms of the provoked tremors have been calculated. Inversion of the SMT enabled determining precisely the depth of the initiated seismic sources (it correlates well with the depth of immediate roof of coal seam numbered 507) and what kind of processes were present within them. The presence of additional processes has been confirmed. In the full solution of the SMT, a shear process dominates. In the foci of tremors after the first and third blasts, a reverse slip mechanism occurred, which was probably a consequence of high horizontal stress in the deflected layer of sandstone and short stope length between the remnant in coal seam no. 507 and the longwall face in a start-up phase, so the normal rock block slip was not possible. Caving was triggered then, but probably in a smaller range. It cannot be excluded that in the case of blast no. 3 the pointwise use of a smaller mass of explosives was not enough. The share of explosion in the focus of the tremor after blast no. 3 was the highest and equalled at $40.5 \%$. Otherwise, it was an exceptional case with the uniaxial tension (5.9\%). In the focus of the tremor after the second blast, a normal slip mechanism clearly dominated $(60.8 \%)$. In the foci of tremors after the last two blasts, a mixed mechanism occurred (normal slip mechanism and implosion). This was probably due to a larger area of hanging roof. Figure 3 shows chosen examples of possible displacement patterns at the sources associated with mining. They explain probable behaviour of crack in the caving zone. Figure $3 \mathrm{a}$ describes a process of simple shear and normal slip mechanism present to the highest degree in the focus of the tremor after blast no. 2. On the contrary, Fig. 3b shows a process of reverse slip mechanism under the condition of appearance of horizontal stress, dominating in the foci of tremors after blasts nos. 1 and 3. In deflected layers of roof rocks, tensile horizontal stress was probably present, which affected the focal mechanism. A probable focal mechanism in the foci of tremors after blasts nos. 4 and 5, being a mix of normal slip mechanism and implosion, is presented in Fig. 3c. Similar displacement pattern is characteristic for larger seismic events associated with mining (Teisseyre 1980a, b; Ortlepp 1993; Mendecki 1997).

The seismic source parameters, which provide additional information about the foci of tremors and to a certain degree about processes occurring there, have been calculated as well. The efficiency of blasts for caving has been reflected in some of them. Characteristic lower values of the corner frequency $f_{o}$, and higher values of the source radius $r$ and the ratio $E_{s} / E_{p}$ indicate the presence of additional processes. Especially the ratio $E_{s} / E_{p}$ shows that in the foci of the provoked tremors a DC (double-couple) force mechanism occurred. The lower value of this ratio for the last two provoked tremors may be correlated with the greater share of non-shear mechanism (implosion), identified earlier by the SMT inversion. The average stress drop $\Delta \sigma$ equals $4.6 \times 10^{5} \mathrm{~Pa}$. According to Mendecki (1997), the average stress drop varies from $10^{4} \mathrm{~Pa}$ for slow events occurring within a softer rock or along existing weak geological features to $10^{8} \mathrm{~Pa}$ for fast and large events rupturing hard, highly stressed and, to a great extent, intact rock. The obtained results are close to the middle of the range described by Mendecki 

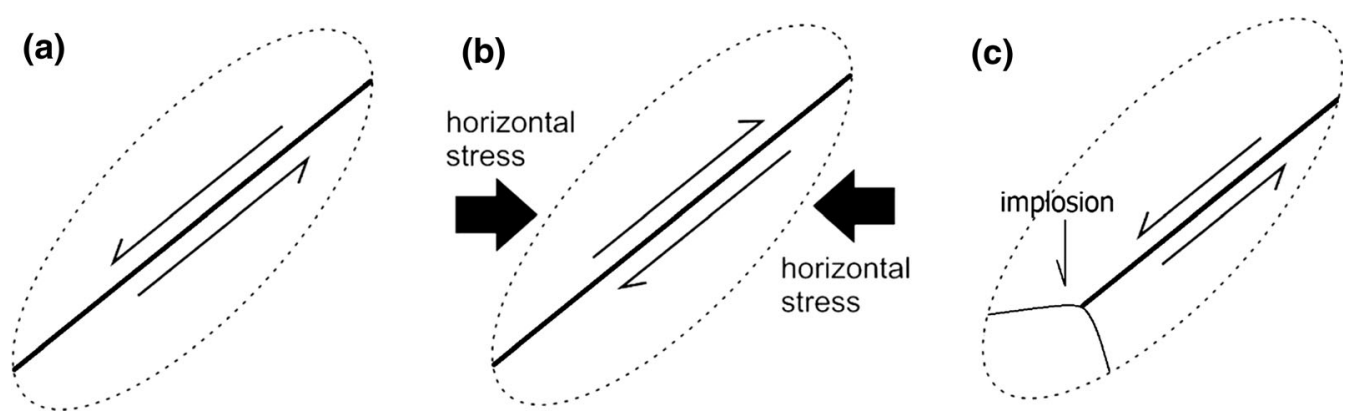

Figure 3

Examples of displacement patterns at seismic sources in mines, where arrows indicate movements at the source: a simple shear, normal slip mechanism; b simple shear under horizontal compression, reverse slip mechanism and c simple shear, normal slip mechanism and implosion associated with stope closure

(1997) but on the side of lower values. Sandstone laying in the immediate roof of coal seam no. 507, as a sedimentary rock, had its own system of fractures. This sandstone was with certain additionally fractured because of its deflection behind the longwall face.

However, seismic events that occur close to the underground excavations and in a complex geological setting frequently exhibit a volumetric character, with many zones of permanent deformation and complex geometry accompanied by a local volume change (Mendecki 1997). The mentioned volumetric character of inelastic deformation can be described by the source volume and/or apparent volume (Mendecki 1997). The source volume is the volume of coseismic inelastic deformation that radiated the recorded seismic waves, and it can be estimated from the seismic moment-to-stress drop ratio. It varies from a fraction of a cubic metre for cracks of about a metre in length to a fraction of a cubic kilometre for large seismic events with source dimension of a few hundred metres (Mendecki 1997). Since apparent stress $\sigma_{a}$ scales with stress drop, and since there is less model dependence in determining the apparent stress than there is in determining corner frequency cubed dependent static stress drop, and because, in general, the stress drop is greater than or equal double apparent stress, thus one can define the apparent volume as seismic moment-to-double apparent stress ratio (Mendecki 1993, 1997). The apparent volume for a given seismic event measures the volume of rock with coseismic inelastic strain with accuracy in the order of magnitude of apparent stress divided by rigidity (Mendecki 1997). In Table 5, both volumes have been set together.

The source volume for tremors provoked after blasts nos. 1, 2 and 4 are comparable, despite the detonation of 2.5 times smaller mass of explosives in the first two cases. Slip of rock blocks can be initiated by an appropriate location of blastholes, even when the mass of explosives is smaller. The geomechanical and local stress conditions play an important role here. However, it should be noted that in the focus of the tremor after blast no. 4 , the stress drop $\Delta \sigma$ was almost two times higher, and the seismic energy $E_{c}$, reflecting the dynamic of processes occurring in a mine tremor, was more than two times higher than that in the foci of the first two provoked tremors. The source volume of the tremor provoked after blast no. 3 was the smallest. This was a consequence of using the smallest mass of explosives, detonated in only one blasthole. This blast was effective, concerning seismic effect or full SMT solution, but on a smaller scale. The highest source volume was in the case of the tremor provoked after the last blast (no. 5). It was probably caused by placing the explosive material in the most exposed roof surface between the longwall face and the remnant in coal seam no. 507. After blast no. 5 , the roof fell down on a large scale, so the next blasting was not necessary. An analogous situation as above concerns the apparent volume.

For the first time, the results of three independent methods used for the estimation of blasting effectiveness were compared with each other and 
Table 5

Comparison of source volume and apparent volume calculated for tremors initiated by blasting for roof caving

\begin{tabular}{llllll}
\hline No. & $Q(\mathrm{~kg})$ & No. of blastholes & $E_{I C M} \times 10^{4}(\mathrm{~J})$ & Source volume $\times 10^{5}\left(\mathrm{~m}^{3}\right)$ & Apparent volume $\times 10^{6}\left(\mathrm{~m}^{3}\right)$ \\
\hline 1. & 48 & 2 & 1 & 1.7 & 5.5 \\
2. & 48 & 2 & 1 & 1.9 & 4.5 \\
3. & 24 & 1 & 0.7 & 0.8 & 1.3 \\
4. & 120 & 5 & 5 & 1.4 & 4.0 \\
5. & 72 & 3 & 3 & 4.4 & 10.5 \\
\hline
\end{tabular}

observations in situ. All of the three methods indicate that blasting for roof caving initiated some other processes behind the longwall face, not only explosion due to the detonation of explosives, and it was confirmed visually in the underground excavation. The seismic effect method enables fast estimation of blasting effectiveness, but without specifying what kind of geomechanical processes occurred in the focus. Such information is collected with the use of the seismic moment tensor inversion method. From seismic source parameters especially the $E_{s} / E_{p}$ ratio is valuable for this purpose. Domination or large presence of slip mechanism in the focus testify about the effectiveness of blasting for caving in hard coal mines, but usually it is combined with the implosion or explosion.

The acknowledgement of the effectiveness of blasting for roof caving may be transferred to other types of blasting, e.g. long-hole destress blasting, which is especially important for rockburst prevention. It looks as though the estimation of seismic source parameters and the seismic moment tensor solution may deliver interesting information describing the initiated process of roof caving and the state of in situ stress existing there.

Open Access This article is distributed under the terms of the Creative Commons Attribution 4.0 International License (http:// creativecommons.org/licenses/by/4.0/), which permits unrestricted use, distribution, and reproduction in any medium, provided you give appropriate credit to the original author(s) and the source, provide a link to the Creative Commons license, and indicate if changes were made.

Publisher's Note Springer Nature remains neutral with regard to jurisdictional claims in published maps and institutional affiliations.

\section{REFERENCES}

Aki, K., \& Richards, P. G. (1980). Quantitative seismology. Theory and methods. San Francisco: W. H. Freeman and Co.

Andrews, D. J. (1986). Objective determination of source parameters and similarity of earthquakes of different size. In S. Das, J. Boatwright, \& C. H. Scholz (Eds.), Earthquake source mechanics (pp. 259-267). Washington, D.C.: American Geophysical Union. https://doi.org/10.1029/GM037p0259.

Backus, G., \& Mulcahy, M. (1976). Moment tensors and other phenomenological descriptions of seismic sources-I. Continuous displacements. Geophysical Journal International, 46(2), 341-361. https://doi.org/10.1111/j.1365-246X.1976.tb04162.x.

Brune, J. N. (1970). Tectonic stress and the spectra of seismic shear waves from earthquakes. Journal of Geophysical Research, 75, 4997-5009. https://doi.org/10.1029/JB075i026p04997.

Caputa, A., Talaga, A., \& Rudziński, Ł. (2015). Analysis of postblasting source mechanisms of mining-induced seismic events in Rudna copper mine, Poland. Contemporary Trends in Geoscience, 4(1), 26-38. https://doi.org/10.1515/ctg-2015-0003.

Dubiński, J., Mutke, G., \& Stec, K. (1996). Focal mechanism and source parameters of the rockbursts in Upper Silesian Coal Basin. Acta Montana, A9(100), 17-26.

Dubiński, J., \& Wierzchowska, Z. (1973). Metody obliczeń energii wstrząsów górotworu na Górnym Śląsku [Methods for the calculation of tremors seismic energy in the Upper Silesia]. Prace GIG, Katowice, 591 (in Polish).

Gibowicz, S. J. (1989). Mechnizmy wstrząsów górniczych [Mechanism of seismic events induced by mining]. Publ Inst Geophys Pol Acad Sci M-13(221) (in Polish).

Gibowicz, S. J. (2009). Seismicity induced by mining: recent research. Advances in Geophysics, 51(C), 1-53. https://doi.org/ 10.1016/S0065-2687(09)05106-1.

Gibowicz, S. J., Cichowicz, A., \& Dybeł, T. (1977). Seismic moment and source size of mining tremors in Upper Silesia, Poland. Acta Gephysica Polonica, 25, 201-217.

Gibowicz, S. J., \& Kijko, A. (1994). An introduction to mining seismology. San Diego: Academic Press.

Hanks, T. C., \& Kanamori, H. (1979). A moment magnitude scale. Journal of Geophysical Research, 84(B5), 2348-2350. https:// doi.org/10.1029/JB084iB05p02348.

Hasegawa, H. S., Wetmiller, R. J., \& Gendzwill, D. J. (1989). Induced seismicity in mines in Canada-an overview. Pure and Applied Geophysics, 129(3-4), 423-453. https://doi.org/10.1007/ BF00874518.

Knotek, S., Matusek, Z., Skrabis, A., Janas, P., Zamarski, B., \& Stas, B. (1985). Research of geomechanics evaluation of rock mass due to geophysical method. Ostrava (in Czech): VVUU. 
Konicek, P., Soucek, K., Stas, L., \& Singh, R. (2013). Long-hole destress blasting for rockburst control during deep underground coal mining. International Journal of Rock Mechanics and Mining Sciences, 61(504), 141-153. https://doi.org/10.1016/j. ijrmms.2013.02.001.

Król, M. (1998). Zastosowanie tensora momentu sejsmicznego i parametrów spektralnych fal sejsmicznych do badania wstrząsów górniczych w kopalni miedzi Polkowice-Sieroszowice [Application of seismic moment tensor and spectral analysis of seismic waves for mine tremor study in copper mine Polkowice-Sieroszowice], Dissertation, Institute of Geophysics, Polish Academy of Sciences (in Polish).

Kwiatek, G., Martínez-Garzón, P., \& Bohnhoff, M. (2016). HybridMT: a MATLAB/shell environment package for seismic moment tensor inversion and refinement. Seismological Research Letters, 87(4), 964-976. https://doi.org/10.1785/0220150251.

Lizurek, G., Rudziński, Ł., \& Plesiewicz, B. (2015). „Mining induced seismic event on an inactive fault. Acta Geophysica, 63(1), 176-200. https://doi.org/10.2478/s11600-014-0249-y.

Lizurek, G., \& Wiejacz, P. (2011). Moment tensor solution and physical parameters of selected recent seismic events at Rudna Copper Mine. In A. F. Idziak \& R. Dubiel (Eds.), Geophysics in mining and environmental protection (pp. 11-19). New York: Springer. https://doi.org/10.1007/978-3-642-19097-1.

Madariaga, R. (1976). Dynamics of an expanding circular fault. Bulletin of the Seismological Society of America, 66(3), 639-666.

McGarr, A., Bicknell, J., Sembera, E., \& Green, R. W. E. (1989). Analysis of exceptionally large tremors in two gold mining districts of South Africa. Pure and Applied Geophysics, 129(3-4), 295-307. https://doi.org/10.1007/BF00874511.

Mendecki, A. J. (1993). Real time quantitative seismology in mines. Keynote lecture. In R. P. Young (Ed.), Rockbursts and seismicity in mines (pp. 287-296). Rotterdam: Balkema.

Mendecki, A. J. (1997). Seismic monitoring in mines. London: Chapman and Hall.

Nitroerg. (2019). http://www.nitroerg.pl/en/products/emulinit-pm. html. Accessed 30 Mar 2019.

Orlecka-Sikora, B., Lasocki, S., Lizurek, G., \& Rudziński, Ł. (2012). Response of seismic activity in mines to the stress changes because of mining induced strong seismic events. International Journal of Rock Mechanics and Mining Sciences, 53, 151-158. https://doi.org/10.1016/j.ijrmms.2012.05.010.

Ortlepp, W. D. (1993). High ground displacement velocities associated with rockburst damage. In R. P. Young (Ed.), Rockbursts and Seismicity in Mines (pp. 101-106). Rotterdam: Balkema.

Rudziński, Ł., Cesca, S., \& Lizurek, G. (2016). „Complex rupture process of the 19 March 2013, Rudna Mine (Poland) induced seismic event and collapse in the light of local and regional moment tensor inversion. Seismological Research Letters, 87(2A), 274-284. https://doi.org/10.1785/0220150150.

Snoke, J. A. (1987). Stable determination of (Brune) stress drops. Bulletin of the Seismological Society of America, 77(2), 530-538.
Srinivasan, C., Sivakumar, C., \& Gupta, R. N. (2005). Source parameters of seismic events in a coal mine in India. In M. A. Wetovsky, J. Benson, \& E. F. Patterson (Eds.), Proceedings of the 27th seismic research review: Ground-based nuclear explosion monitoring technologies, United States, pp. 653-662.

Stec, K. (2007). Characteristics of seismic activity of the Upper Silesian Coal Basin in Poland. Geophysical Journal International, 168(2), 757-768. https://doi.org/10.1111/j.1365-246X. 2006.03227.x.

Sykes, L. R. (1967). Mechanism of earthquakes and nature of faulting on the mid-oceanic ridges. Journal of Geophysical Research, 72(8), 2131-2153. https://doi.org/10.1029/ JZ072i008p02131.

Teisseyre, R. (1980a). Some remarks on the source mechanism of rockbursts in mines and on the possible source extension. Acta Montana CSAV Praha, 58, 7-13.

Teisseyre, R. (1980b). Earthquake premonitory sequence-dislocation processes and fracturing. Bollettino di Geofisica Teorica e Applicata, 22(88), 245-254.

Trifu, C. I., Urbancic, T. I., \& Young, R. P. (1995). Source parameters of mining-induced seismic events: an evaluation of homogeneous and inhomogeneous faulting models for assessing damage potential. Pure and Applied Geophysics, 145(1), 3-27. https://doi.org/10.1007/BF00879480.

Wojtecki, Ł., \& Konicek, P. (2016). „Estimation of active rockburst prevention effectiveness during longwall mining under disadvantageous geological and mining conditions. Journal of Sustainable Mining, 15(1), 1-7. https://doi.org/10.1016/j.jsm. 2016.04.003.

Wojtecki, Ł., Konicek, P., Mendecki, M. J., \& Zuberek, W. M. (2017a). Application of seismic parameters for estimation of destress blasting effectiveness. Procedia Engineering, 191, 750-760. https://doi.org/10.1016/j.proeng.2017.05.241.

Wojtecki, Ł., Mendecki, M. J., Talaga, A., \& Zuberek, W. M. (2013). The estimation of the effectiveness of torpedo blasting based on an analysis of focal mechanisms of induced mining tremors in the Bielszowice coal mine. In M. Kwasniewski \& D. Łydzba (Eds.), Rock mechanics for resources, energy and environment (pp. 769-773). London: Taylor and Francis Group. https://doi.org/10.1201/b15683-131.

Wojtecki, Ł., Mendecki, M. J., \& Zuberek, W. M. (2016a). The seismic source parameters of tremors provoked by destress blastings in coal seam. Journal of Mining Science, 52(2), 258-264. https://doi.org/10.1134/S1062739116020382.

Wojtecki, Ł., Mendecki, M. J., \& Zuberek, W. M. (2017b). Determination of destress blasting effectiveness using seismic source parameters. Rock Mechanics and Rock Engineering, 50(12), 3233-3244. https://doi.org/10.1007/s00603-017-1297-9.

Wojtecki, Ł., Mendecki, M. J., Zuberek, W. M., \& Knopik, M. (2016b). An attempt to determine the seismic moment tensor of tremors induced by destress blasting in a coal seam. International Journal of Rock Mechanics and Mining Sciences, 83, 162-169. https://doi.org/10.1016/j.ijrmms.2016.01.002. 